sciendo $\quad$ Zagreb International Review of Economics \& Business, Vol. 23, No. 1, pp. 1-18, 2020 (C) 2020 Faculty of Economics and Business, University of Zagreb and De Gruyter Open

All rights reserved. Printed in Croatia ISSN 1331-5609; UDC: $33+65$

DOI: $10.2478 /$ zireb-2020-0001

\title{
Does Working Capital Management Affect Profitability of Ghanaian Manufacturing Firms?
}

\author{
Kwadwo Boateng Prempeh* \\ Godfred Peprah-Amankona**
}

\begin{abstract}
This paper analyses the link between working capital management and profitability of firms in the context of developing economies. A balanced panel consisting of eleven (11) manufacturing firms listed on the Ghana Stock Exchange covering the period of 2011-2017 was used. The link between working capital management and profitability was examined using dynamic panel regression (Arellano-Bond Estimation) technique. The study revealed that there is a significant positive linear relationship between working capital management and firms' profitability. The findings also reveal the existence of a concave quadratic relationship between working capital management and firms' profitability. There is an optimal level at which working capital management maximises firm's profitability, therefore, managers need to ensure that they operate within the limits of the optimal level by implementing an effective and efficient working capital management policy. The study concludes that, the practice of an aggressive working capital management policy maximises a firm's profitability.
\end{abstract}

Keywords: working capital management; cash conversion cycle; dynamic panel regression; manufacturing firms; profitability

\section{JEL Classification:}

\section{Introduction}

Working capital management is one of the most essential and delicate aspects of the overall business finance that demands meticulous attention in all firms irrespective of the size, type or the nature of business (Deloof, 2003; Dinku, 2013; Korent \& Orsag,

\footnotetext{
* Kwadwo Boateng Prempeh is at Sunyani Technical University Sunyani, Brong Ahafo, Ghana. E-mail: prempeh.boateng@stu.edu.gh

** Godfred Peprah-Amankona is at Finance Directorate, Sunyani Technical University, Ghana. E-mail: peprahamankona@gmail.com
} 
2018). The importance of working capital cannot be overemphasized when it comes to corporate finance because of its direct effect on the solvency and profitability of the firm (Raheman \& Nasr, 2007; Aktas, Croci, \& Petmezas, 2018). The efficient management of working capital is very crucial, especially for manufacturing companies, due to the fact that current assets (i.e. inventory and trade receivables) constitute a major portion of their assets (Arunkunar \& Ramanan, 2013; Ponsian, Chrispina, Tago, \& Mkiibi, 2014).An efficient working capital management policy plays an essential part in the overall corporate strategy in maximizing shareholders' value (Ray, 2012).

Efficient working capital management involves the judicious planning and controlling of current assets and current liabilities in a manner that eliminates or reduces the risk that the firm in consideration would not be able to meet its current liabilities or avoid maintaining an excessive level of the working capital requirements (Eljelly, 2004). If a firm invests excessively in working capital (i.e. more than the level required) the returns that can be gained by investing these resources in long term assets diminishes (Ponsian, Chrispina, Tago, \& Mkiibi, 2014), the firm also has to bear the cost of holding as well as handling inventory for a longer period (Arnold, 2008). If funds invested in inventories, cash, or trade receivables is inadequate, the firm will find it difficult in meeting its operation cost (Napompech, 2012). This is going to reduce the level of sales and profit in the long term (Deloof, 2003; Eramus, 2010).

A firm seeking to maximize profit should maintain a balance between current assets and current liabilities and, thus, being up-to-date with the tradeoff between liquidity and profitability (Ani, Okwo, \& Ugwunta, 2012). Maximizing profit to the detriment of liquidity can cause the organisation serious problems and vice-versa. Therefore, firms can reduce risk and increase their overall performance by understanding the role and drivers of working capital management (Nazir \& Afza, 2009). Effective working capital management affects the survival of the firm, the continuity of its of operations, and the maintenance of liquidity and profitability (Evci \& Şak, 2018). In this context, this study aims at examining in detail the trade-off between working capital management and firm's profitability.

Various components of working capital management that have the tendency of affecting the profitability of manufacturing firms have been used as proxies (variables) for working capital management in existing studies. In this study, the predictor variables selected was based on different theories relating to working capital management and profitability and other variables were also included as a result of the impact they had on the results of previous studies. Due to limited access to data, certain variables used in previous studies were not included in the study. Therefore, the five (5) proxy variables included in the study are, cash conversion cycle, firm size, leverage, current ratio and return on assets.

Most of the previous works on this essential topic covered developed economies, hence, there is scanty work covering emerging/developing economies. Aregbeyen (2013), Dinku (2013), Gachira, Chiwanzwa, Nkomo and Chikore (2014), and Pon- 
sian et. al. (2014) examined the relationship between working capital management and profitability by collecting data from firms in Nigeria, Ethiopia, Zimbabwe and Tanzania respectively. This study which collected data from Ghanaian manufacturing firms listed on the Ghana Stock Exchange (GSE) is an extension of those studies. Generalization of the findings of this study may be applicable to all manufacturing firms in developing economies. It will help managers and policymakers in the determination of the optimal working capital, and also help them when it comes to the distribution among the working capital components. It will ensure the effective and efficient use of scarce resources and also help to maintain a working capital level that will maximise profitability, thereby, ensuring the sustainability of future investment.

This study contributes to existing literature in terms of evaluating the relationship between working capital management and profitability of firms in emerging economies. The main focus of this study is on Ghanaian manufacturing firms, where only limited studies have been conducted recently (Akoto, Awunyo-Vito, \& Angmor, 2013; Prempeh, 2016). Also, the study seeks to confirm the findings of some of the previous researchers by examining the relationship between working capital management and the profitability of the sample firms. The study, therefore, will help substantiate an existing theory developed by previous authors. Thus, the study will be valuable to both researchers and managers.

\section{Literature Review}

Many studies have evaluated the relationship between working capital management and profitability in various parts of the world and the findings are quite divergent. A majority of the studies established an inverse relationship between working capital management and profitability of firms. Furthermore, most of the previous studies favor the aggressive working capital approach which states that reducing the amount invested in working capital affects profitability positively by reducing the composition of current assets in total assets. Ordinary Least Square Regression (OLS) and Panel Data Regression were the main analysis techniques employed by previous authors who studied the link between working capital management and firms' profitability. To identify pertinent areas not covered by previous studies, major studies related to this study have been reviewed in this section.

To establish the relationship between working capital management and profitability Deloof (2003) in his study, sampled 1,009 large Belgian non-financial firms over the period 1992-1996. The main analysis techniques employed were Pearson correlation and regression tests which established an inverse association between profitability measured by gross operating income and the number of days account receivables, inventories and account payables which were the proxies for working capital management. Eljelly (2004) conducted a similar study using a sample of 29 joint 
stock companies in Saudi Arabia for the period 1996-2000. Adopting the Pearson Correlation method and regression analysis, he found a significant negative relationship between the firms' profitability and its liquidity level. This relation was much stronger in firms with high current ratios and relatively longer cash conversion cycles.

Padachi (2006) using a sample of 58 Mauritian Small Firms using panel data analysis (regression analysis) covering the period 1998-2003 found a negative relationship between the number of days of accounts receivables, accounts payables, cash conversion cycle, inventory days and profitability. The results also indicated that high investments in inventories and receivables reduce the profitability of the firm. These findings support the aggressive working capital management policy. Lazaridis and Tryfonidis (2006) in their bid to investigate the relationship between corporate profitability and working capital management used a sample of 131 companies listed on the Athens Stock Exchange (ASE) for the period 2001-2004. The study established a statistically significant inverse relationship between gross operating profit, the proxy for profitability and cash conversion cycle which was the main proxy for working capital management. This conclusion was derived from the regression analysis.

Raheman and Nasr (2007) established a negative relationship between working capital variables and profitability. the study samples 94 firms listed on the Krachi Stock Exchange (KSE) in Pakistan for the period 1999-2004. Pearson's Correlation, and regression analysis (Pooled Least Square and general Least square with cross section weight models) were the main data analysis techniques used in the study. Garcıa-Teruel and Martınez-Solano (2007) conducted a cross-sectional study by collecting data from a sample of 8872 small to medium enterprises in Spain covering the period of 1996-2002 and the estimation was done using the generalized least square regression. The study concluded that a statistically significant negative relationship exists between all the measures of working capital management (number of days accounts receivable; number of days of inventory; number of days accounts payable; cash conversion cycle) and profitability.

Uyar (2009) examined a sample of 166 listed corporations on the Istanbul Stock Exchange (ISE) for the year 2007 using ANOVA and Pearson Correlation analyses found a significant negative relationship between cash conversion cycle and profitability. In Kenya, Mathuva (2010) in his bid to test the influence of working capital management components on corporate profitability, surveyed 30 firms in Kenya which were listed on the Nairobi Stock Exchange (NSE) between the period 1992 to 2008. The study established a positive relationship between inventory conversion period, average payment period and profitability but an inverse relationship between accounts collection period and profitability. Fixed effects regression models were used. In a similar study, Gill, Biger, and Mathur (2010), using a sample of 88 American firms listed on New York Stock Exchange for a period of 3 years from 2005 to 2007, established a positive significant relationship between cash conversion cycle and profitability by employing the Weighted Least Square Regression (WLS) technique. 
Sharma and Kumar (2011) evaluated the effect of different variables of working capital management including number of days accounts receivables, number of days inventory, number of days accounts payable, and cash conversion cycle on profitability of Indian firms. They selected a sample of 263 non-financial firms listed on the Bombay Stock Exchange (BSE) from 2000 to 2008 and evaluated the data using OLS multiple regression. The results revealed that working capital management and profitability is positively correlated in Indian companies. The study further revealed that inventory number of days and number of days accounts payable are negatively correlated with a firm's profitability, whereas number of days accounts receivables and cash conversion period exhibit a positive relationship with corporate profitability. Alipour (2011) conducted a cross-sectional study by using 1068 companies listed on the Tehran Stock Exchange for the period 2001-2006. The results of the statistical test of the hypothesis indicate that there is a negative significant relationship between number of days accounts receivable, Inventory turnover in days, number of days accounts payables, cash conversion cycle and profitability.

Ray (2012) investigated the relationship between working capital management components and profitability of a sample of Indian manufacturing firms using a sample of 311 Indian manufacturing firms for a period of 14 years from 1996-97 to 2009-10. The result suggests a strong negative relationship between the measures of working capital management including the number of days accounts receivable, cash conversion cycle, financial debt ratio, and profitability. Vahid, Elham, Mohsen and Mohammadreza (2012) after studying 50 different companies listed on Tehran Stock Exchange (TSE) during the period 2006 to 2009 using multiple regression analysis found a negative and significant relationship between the variables of average collection period, Inventory Turnover in day, Average Payment Period, Net Trading Cycle and the performance of firms.

Aregbeyen (2013) empirically investigated the effects of WCM on the profitability of 48 large companies listed on the Nigerian Stock Exchange (NSE) for the period 1993 to 2005 using the Pearson Correlation analysis and regression analysis. They indicated that all the measures of working capital (Average Collection Period, Average Payment Period, cash conversion cycle and inventory turnover in days) are negatively related to profitability. Akinlo (2013) researched the relationship between working capital management and profitability of 66 Nigerian non-financial firms for the period 1997-2007. Using regression analysis (Pooled OLS and Fixed effect), he found a negative significant relationship between number of days inventories, number of days accounts payable and profitability. The relationship between the cash conversion cycle and profitability was negative and statistically insignificant.

Gachira, Chiwanzwa, Nkomo and Chikore (2014) analysed a sample of 39 non-financial firms listed in the Zimbabwe Stock Exchange (ZSE) from 2009-2013 using the linear regression analysis. The results of their study show that there are mixed effects of the components of working capital and profitability. Using debt to asset 
ratio as a control variable, they found a positive relationship between debtor days, cash conversion cycle and profitability but found a negative relation between creditor days and profitability. Ukaebe (2014) adopting a pooled OLS approach using a balanced data of manufacturing firms in Egypt, Kenya, Nigeria and South Africa for the period of 2005-2009 found a strong negative relationship between profitability, measured through net operating system profit, and cash conversion cycles across different industrialization typologies. The inverse association implies that when the cash conversion cycle increases, the profitability of the firm decreases. Nikkinen, Graham and Enqvist(2014) using a sample of firms listed on the Nasdaq OMX Helsinki Stock exchange between the years 1990-2000 (1136 firm-year observation) and adopting the regression analysis, found out that there exists a negative significant relationship between Cash conversion cycle and profitability. Ponsian, Chrispina, Tago and Mkiibi (2014) assessed the effect of working capital management on profitability using a sample of 3 manufacturing companies listed on the Dares Salaam Stock Exchange (DSE) for the period 2002-2013 using the ordinary least square regression analysis, it was found out that there was a positive relationship between cash conversion cycle, average payment period and profitability of the firm, but a highly significant negative relationship between inventory turnover in days, average collection period, and profitability.

Pais and Gama (2015) in their bid to provide empirical evidence on the effects of working capital management on firms' profitability, sampled 6063 Portuguese small and medium-sized firms covering the period 2002-2009. Panel data regression (Fixed effect) was used for the analysis. It was revealed that there was an inverse relationship between profitability and the working capital variables (i.e. number of days of inventory, number of days accounts payable, number of days accounts receivable, cash conversion cycle). In Sri Lanka, Kodithuwakku (2015), studied the impact of working capital management on profitability using a sample of 20 manufacturing companies listed on the Colombo Stock Exchange (CSE) for the period of 2008 to 2012 using the Pearson correlation and ordinary least square regression. The study found a negative relationship between profitability, debtors collection period, inventory conversion period and cash conversion cycle but a positive relationship between profitability and creditors conversion period using financial leverage, sales growth and firm size as control variables.

Afrifa and Tingbani (2017) in their study adopted the panel data regression analysis on a sample of 802 British quoted small and medium enterprises listed on the Alternative Investment Market for the period 2004 to 2013. From their analysis, it was found that the relationship between profitability and cash conversion cycle for firms with cash flow below the sample median is negative whilst the association between cash conversion cycle and profitability for firms with cash flow above the sample media is statistically significant and positive. In South Africa, Kasozi (2017), examined working capital management and its impact on financial performance us- 
ing an unbalanced panel of 69 manufacturing firms listed on the Johannesburg Securities Exchange during the period 2007-2016. The findings revealed that the average collection period and the average payment period are negative and statistically significant for profitability and that a significant positive relationship exists between the number of days in inventory and profitability.

In order to provide empirical evidence of the tradeoff between working capital and firms' profitability, Evci and Şak, (2018) using annual data of 41 firms listed on Borsa Istanbul Industry Index for the period 2005-2016. Theworking capital components and firm's profitability tradeoff was examined via the fixed effects panel regression model. Findings showed the existence of a tradeoff between working capital management and profitability. A negative relationship exists between return on assets and payables deferral period, cash conversion cycle, the ratio of short-term financial debts to short-term debts, and the ratio of fixed assets to total assets while return on assets is positively related to inventory conversion period and sales growth. Jana (2018) examined the relationship between working capital management and profitability using all the 15 listed FMCG Company covering the period 2013-2017. Using panel data analysis, the study finds a significant negative and positive relationship between profitability and working capital management. Korent and Orsag (2018) using a sample of 443 Croatian firms consisting of firms classified into Group 62 covering the period 2008-2013 and using dynamic panel regression analysis, found a statistically significant concave quadratic relationship between networking capital and company's profitability.

In Ghana, Akoto, Awunyo-Vito and Angmor (2013) examined the relationship between working capital management practices and profitability for a sample of 13 listed firms on the Ghana Stock Exchange for the period 2005-2009 using the Ordinary Least square regression (OLS). The study reveals a significantly negative relationship between profitability and accounts receivable days. However, the firms' cash conversion cycle, current asset ratio, size, and current asset turnover significantly positively influence profitability. Prempeh (2016) using a sample of 4 companies listed on the Ghana Stock Exchange for the period 2004 to 2014 using the Ordinary Least Square Regression (OLS) examined the relationship between efficient inventory management on profitability. The study revealed a significantly positive relationship between the main variable, raw materials inventory management and profitability.

To summarize, the literature review shows that working capital management impacts on the profitability of the firm but there are still divergent views regarding the appropriate variables that might serve as proxies for working capital management and profitability. In line with previous empirical studies relating to the impact of working capital management on profitability of firms, this study tests the hypothesis of the existence of a linear relationship between working capital management and profitability of Ghanaian manufacturing firms listed on the Ghana Stock Exchange (GSE). Findings of most studies seek to suggest that an aggressive working capital 
management strategy has a statistically significant positive relationship with profitability of the firms studied.

H1: There exists a significant positive relationship between aggressive working capital management strategy and profitability of Ghanaian Manufacturing firms listed on the Ghana Stock Exchange (GSE).

Base on the recommendation of Korent \& Orsag (2018) about exploring the non-linear relationship between working capital management and profitability, the second hypothesis assumes the existence of a concave quadratic relationship between working capital management and profitability of Ghanaian manufacturing firms listed on the Ghana Stock Exchange (GSE).

H2: There exists a significant concave quadratic relationship between working capital management and profitability of Ghanaian Manufacturing Firms listed on the Ghana Stock Exchange (GSE).

\section{Methodology}

\section{Sample}

The sample for this study consists of Ghanaian manufacturing firms listed on the Ghana Stock Exchange (GSE). The firms should have been listed on the stock exchange and generating revenue and recording profit for the period of 2011-2017. These firms were included in the sample because of the availability of data and its relevance in the context of economic growth and employment potentials, which stresses the need for an effective and efficient working capital management in the selected firms. A balanced panel of 11 firms was formed after firms that exited from the stock market between 2011 and 2017 were excluded from the study.

\section{Data and Variables}

The data used in this study was extracted from the annual financial statements of manufacturing firms listed on the Ghana Stock Exchange. The data obtained is secondary in nature and was obtained from the Ghana Stock Exchange official website. Firms data included basic information about the firms and quantitative (financial and non-financial) data that were needed to calculate the variables at the company level which can be pooled together to form the panel data. The choice of predictor variables is based on alternative theories relating to working capital management and profitability and also, the availability of data needed for their calculation and their frequency and relevance in previous studies.

The return on assets (ROA) was operationalized as the proxy for profitability which is the dependent variable. The ROA is the ratio of net income to total as- 
sets multiplied by 100 . The proxy operationalized as the explanatory variable and a measure for working capital management is cash conversion cycle (CCC). The Cash Conversion Cycle (CCC) was measured as the number of days of account receivable (AR) plus number of days in inventory (INV) minus number of days of accounts payable (AP). The number of days of accounts payable (AP) was measured as the ratio of accounts payable to cost of goods sold multiplied by 365 days, number of days in inventory (INV) was measured as the ratio of inventory to cost of goods sold multiplied by 365 days. Number of day accounts receivables (AR) was measured as the ratio of accounts receivables to sales multiplied by 365 days. The three (3) variables were then combined to measure the cash conversion cycle.

In addition to these variables, firm size (SIZE), firm leverage (LEV) and current ratio (CR) were introduced as control variables. Control variables were introduced into the model to increase the robustness of the model. The control variables have a significant effect on the validity of the study. Firm Size was measured as the natural logarithm of total assets, leverage was measured as the ratio of debt to equity, and current ratio was measured as the ratio of current assets to current liabilities.

\section{Methods and Regression Models Specification}

Descriptive analysis is primarily used to describe the sample. To test the impact of working capital management on the profitability of listed manufacturing companies on the Ghana Stock Exchange (GSE), inferential statistic- correlation and panel regression analysis is used. In order to test for hypothesis 1 and Hypothesis 2, the following dynamic panel regression models are estimated using Arellano-Bond Estimator:

$$
\begin{gathered}
R O A_{i t}=\beta_{0}+\beta_{1} R O A_{i t-1}+\beta_{2} C C C_{i t}+\beta_{3} L E V_{i t}+\beta_{4} C R_{i t}+\beta_{5} S I Z E_{i t}+\varepsilon_{i t} \\
R O A_{i t}=\beta_{0}+\beta_{1} R O A_{i t-1}+\beta_{2} C C C_{i t}+\beta_{3} C C C_{i t}^{2}+\beta_{4} L E V_{i t}+\beta_{5} C R_{i t}+\beta_{6} S I Z E_{i t}+\varepsilon_{i t}
\end{gathered}
$$

The dynamic panel regression model (i.e. Arellano-Bond estimator) is employed in this study due to the findings of previous studies. From the results it is evident that there is the problem of endogeneity resulting from the presence of reverse causality and/or bias caused by omitted variables. The relationship that exists between working capital management and profitability is bidirectional meaning, it is not only working capital management that affects profitability but profitability also has an effect on the management working capital. As opined by (Korent \& Orsag, 2018), there is also the probability of unobserved individual effects correlated with the individual variables in the model. Hence, the dynamic panel model is more appropriate considering the fact that it takes into account the dynamic nature of the firms' profitability and potentially mitigates against endogeneity problem. The presence of the lagged dependent variable as an independent variable in the dynamic panel model 
helps to control for endogeneity problem and control for omitted variable bias. In this study, the problem of endogeneity is solved by employing the Arellano-Bond estimator which eliminates unobservable individual effects by first order differencing and includes in model internal instrumental variables and control for correlation between dependent variable difference and error term. Lastly, the coefficients of working capital management variables and the square of it can be used to determine the breakpoint in working capital management and profitability relation as:

$\frac{-\beta_{2}}{2 \beta_{3}}$. To confirm hypothesis 2 , this should be a maximum, because it is an indication that a concave quadratic relationship exists between working capital management and profitability and, thus, firms have an optimal working capital management level that maximises profitability.

\section{Empirical Analysis}

\section{Descriptive Statistics}

The descriptive statistics of the variables that are included in the model are presented in Table 1 (see appendix). Since the data was asymmetric (skewed), the median was employed as a measure of the central tendency. From the results, the median return on assets (ROA) is 0.068 . Normally, any amount invested is expected to yield a return of $6.8 \%$. The cash conversion cycle (CCC) has a median of 50.93. This shows that manufacturing firms are able to turn over their stocks 7.2 times in a year. The median for the current ratio (CR) is 1.42 . This is an indication that the current assets of manufacturing companies in Ghana are able to meet the current liabilities almost 1.5 times. The median for leverage was $.8569(85.7 \%)$. This shows that manufacturing firms in Ghana use more debt financing, hence, they are highly geared. The median firm size is 7.61 .

\section{Correlation Analysis}

The result of the correlation analysis is presented in Table 2. The results show that return on assets is positively related to cash conversion cycle (CCC). The coefficient of the working capital variable was significant. A positive relationship between ROA and cash conversion cycle (CCC) is an indication that profitable Ghanaian manufacturing firms take a relatively longer number of days to convert its investments in inventory and other resources into cash flows from sales. A significant positive relationship between firm size and ROA shows that large firms tend to make more profits than small firms. 
Table 2: Correlation Matrix

\begin{tabular}{|c|c|c|c|c|c|}
\hline Variable & ROA & CCC & CR & LEV & SIZE \\
\hline ROA & 1 & & & & \\
\hline CCC & $.807^{* *}$ & 1 & & & \\
\hline CR & .221 & $.295^{* *}$ & 1 & & \\
\hline LEV & -0.007 & -.092 & -.052 & 1 & \\
\hline SIZE & $.335^{* *}$ & .119 & -.050 & .046 & 1 \\
\hline
\end{tabular}

$* \mathrm{p}<0.05, * * \mathrm{p}<0.01$

\section{Hypothesis Testing}

Hypothesis 1 was tested using 4 dynamic panel regression models: Arellano-Bond with default standard errors, Arellano-Bond with standard errors and control variables as predictor variables, Arellano-Bond with Robust standard errors, and Arellano-Bond with Robust standard and control variables as predictor variables. The results are displayed in Table 3. The results indicate that the dynamic panel regression models that did not include the control variables as predictor variables at a significant level of $1 \%$, a percentage unit increase in working capital management will increase the firms' profitability by .3106752 percentage unit. However, when the control variables were included in the model as predictor variables, at a significant level of $1 \%$, a positive relationship exists between the working capital management variable and the profitability variable. Thus, a percentage unit increase in working capital management will increase firms' profitability by .280661 percentage unit. Findings from the results suggest that hypothesis one cannot be rejected. Empirical findings confirm the existence of a positive linear relationship between aggressive working capital management policy and profitability of Ghanaian manufacturing firms. This finding is consistent with previous empirical findings (Afrifa \& Tingbani, 2017; Gachira, Chiwanzwa, Nkomo, \& Chikore, 2014; Ponsian, Chrispina, Tago, \& Mkiibi, 2014; Akoto, Awunyo-Vito, \& Angmor, 2013; Mathuva, 2010) which established a positive linear relationship between working capital and firms' profitability. The positive relationship between profits (ROA) and cash conversion cycle (CCC) might be as a result of the nature of firms and the high profits they accrue by virtue of them dominating the Ghanaian market. Profitable manufacturing firms normally keep in a high level of inventory to take care of seasonal demands and avoid the costs associated with holding inadequate stocks and fluctuations in prices of raw materials. 
Table 3: Panel Regression Results for Hypothesis 1

\begin{tabular}{|c|c|c|c|c|}
\hline & (1) & (2) & (3) & (4) \\
\hline & ABE_SE & ABE_SE AND CV & ABE_ROBUST & ABE_ROBUST AND CV \\
\hline CONS & $\begin{array}{c}-8.568988^{*} \\
(-2.30)\end{array}$ & $\begin{array}{c}-545.969 * * \\
(-3.99)\end{array}$ & $\begin{array}{c}-8.568988^{*} \\
(4.40)\end{array}$ & $\begin{array}{c}-545.969 * \\
(-3.37)\end{array}$ \\
\hline $\mathrm{ROA}_{\mathrm{LAG} 1}$ & $\begin{array}{l}-2.30 * \\
(-3.50)\end{array}$ & $\begin{array}{c}.0514103^{*} \\
(4.11)\end{array}$ & $\begin{array}{c}-.2702731^{*} \\
(-4.29)\end{array}$ & $\begin{array}{c}.0514103^{*} \\
(3.22)\end{array}$ \\
\hline $\mathrm{CCC}$ & $\begin{array}{c}.3106752 * * \\
(15.67)\end{array}$ & $\begin{array}{c}.280661 * * \\
(13.97)\end{array}$ & $\begin{array}{c}.3106752 * * \\
(6.92)\end{array}$ & $\begin{array}{c}.280661^{* *} \\
(13.10)\end{array}$ \\
\hline CR & & $\begin{array}{c}2.610394 \\
(0.80)\end{array}$ & & $\begin{array}{c}2.610394 \\
(1.37) \\
\end{array}$ \\
\hline LEV & & $\begin{array}{c}.0447698 * * \\
(2.78)\end{array}$ & & $\begin{array}{c}.0447698^{* *} \\
(9.12)\end{array}$ \\
\hline SIZE & & $\begin{array}{c}71.05856 * * \\
(03.87)\end{array}$ & & $\begin{array}{c}71.05856^{* *} \\
(3.15)\end{array}$ \\
\hline $\begin{array}{l}\text { Wald } \mathrm{Chi}^{2} \\
\text { Prob }>\mathrm{Chi}^{2}\end{array}$ & $\begin{array}{l}317.37 \\
0.0000\end{array}$ & $\begin{array}{l}559.10 \\
0.0000\end{array}$ & $\begin{array}{c}49.62 \\
0.0000\end{array}$ & $\begin{array}{c}1333.67 \\
0.0000\end{array}$ \\
\hline
\end{tabular}

Note: $* \mathrm{p}<0.05, * * \mathrm{p}<0.01$ Arellano-Bond estimator with standard errors (ABE_SE), Arellano-Bond estimator with standard errors and control variables (ABE_SE and CV), Arellano-Bond estimator with Robust standard errors (ABE_Robust), Arellano-Bond estimator with Robust standard errors and control variables (ABE_Robust and CV).

The results obtained for hypothesis 2 is reported in Table 4. Consistent with the predictions, the results confirm a statistically significant concave quadratic relationship between working capital management strategy and firms' profitability since the coefficient of the CCC variable is positive $\left(\beta_{2}>0\right)$ and the coefficient for its square $\left(\mathrm{CCC}^{2}\right)$ is negative $\left(\beta_{3}>0\right)$. The coefficient for the working capital management proxy and its square are statistically significant at $1 \%$ and $5 \%$ respectively depending on the model. The results indicate that there is an optimum level of working capital management which maximises the profitability of manufacturing firms in Ghana. Results of observed models which excluded the control variables as predictor variables show that optimal level of working capital management in the total sales (revenue) of the firm amounts to $89.26 \%$. Thus, holding all other things constant, the maximum profitability of Ghanaian manufacturing firms is achieved when the firm holds working capital more than three-quarters of the value of the firm's total sales. This shows that the annual turnover of working capital is $0.89(\approx 1)$, and manufacturing firms in Ghana need to ensure financing of the working capital for an average of 324.85 days. When the control variables were included in the dynamic regression model as predictor variables, the optimal level of working capital increased slightly to $90.71 \%$. This finding supports the conservative working capital policy, which stipulates that firms should maintain a high level of working capital in order to reduce risk. From the empirical results presented in Table 4, Hypothesis 2 cannot be rejected. The finding of this study is consistent with the findings of previous studies (Korent \& Orsag 2018; 
Garcıa-Teruel \& Martınez-Solano 2007) which established a concave quadratic relationship between working capital management and profitability.

Table 4: Panel Regression Results for Hypothesis 2

\begin{tabular}{|l|c|c|c|c|}
\hline & $(\mathbf{1})$ & $\mathbf{( 2 )}$ & $\mathbf{( 3 )}$ & $(\mathbf{4})$ \\
\cline { 2 - 5 } & ABE_SE & ABE_SE AND CV & ABE_ROBUST & ABE_ROBUST AND CV \\
\hline \multirow{2}{*}{ CONS } & $\begin{array}{c}7.491435^{* *} \\
(4.73)\end{array}$ & $\begin{array}{c}6.290507^{* *} \\
(0.09)\end{array}$ & $\begin{array}{c}7.491435^{*} \\
(3.83)\end{array}$ & $\begin{array}{c}6.290507 \\
(0.08)\end{array}$ \\
\hline \multirow{2}{*}{ ROA $_{\text {LAG1 }}$} & $\begin{array}{c}-.0172621 \\
(-0.09)\end{array}$ & $\begin{array}{c}.022087^{*} \\
(0.11)\end{array}$ & $\begin{array}{c}-.0172621^{*} \\
(-2.08)\end{array}$ & $\begin{array}{c}.022087^{*} \\
(2.14)\end{array}$ \\
\hline \multirow{2}{*}{ CCC } & $.0324543^{*}$ & $.032747^{*}$ & $.0324543^{* *}$ & $.032747^{*}$ \\
& $(1.90)$ & $(1.67)$ & $(4.55)$ & $(2.47)$ \\
\hline CCC_SQR & $-.0001818^{* *}$ & $-.0001805^{* *}$ & $-.0001818^{* *}$ & $-.0001805^{* *}$ \\
& $(-17.92)$ & $(-14.39)$ & $(-47.03)$ & $(-17.19)$ \\
\hline \multirow{2}{*}{ CR } & & $3.838663^{* *}$ & & $3.838663^{* *}$ \\
& & $(2.68)$ & & $(3.50)$ \\
\hline \multirow{2}{*}{ LEV } & & .0014663 & & $.0014663^{* *}$ \\
& & $(0.19)$ & & $(0.48)$ \\
\hline \multirow{2}{*}{ SIZE } & & $(-0.10)$ & & -.9422607 \\
& & 3052.25 & 18293.24 & $(-0.09)$ \\
\hline Wald Chi ${ }^{2}$ & 2808.87 & 0.0000 & 0.0000 & 57486.03 \\
Prob>Chi ${ }^{2}$ & 0.0000 & & & 0.0000 \\
\hline
\end{tabular}

Note: ${ }^{*} \mathrm{p}<0.05, * * \mathrm{p}<0.01$ Arellano-Bond estimator with standard errors (ABE_SE), Arellano-Bond estimator with standard errors and control variables (ABE_SE and CV), Arellano-Bond estimator with Robust standard errors (ABE_Robust), Arellano-Bond estimator with Robust standard errors and control variables (ABE_Robust and CV).

\section{Conclusion}

The main aim of this study is to evaluate the relationship between working capital management and profitability of Ghanaian manufacturing firms listed on the Ghana Stock Exchange. The study was conducted using a balanced panel sample of 11 firms for the period 2011 to 2017. Dynamic Panel Regression Model (Arellano-Bond Estimation) which allows for the unobserved heterogeneity and endogeneity control was the technique employed to analyse the data. In addition to previous empirical studies, this study tested for both the linear and concave quadratic relationship that exists between working capital management and profitability of firms in developing economies using manufacturing firms listed on the Ghana Stock Exchange. This analysis which previous studies have overlooked in the past, reveals that there is an optimal level of working capital management which maximises firm's profitability. This is an indication that there is an optimal level of working capital management that brings a balance between cost and benefits, hence, maximizing profit. The implication is that firms operating below the optimal level will experience an increase in profit 
when the level of working capital management increases (i.e. conservative working capital management strategy) whilst for firms operating above the optimal level an increase in the working management will result in a decrease in profitability. The latter supports the aggressive working management strategy. Results of the study after testing for hypothesis 1 (all the models) indicate that an increase in working capital management is associated with an increase in profitability. This finding supports the conservative working capital management strategy.

This study has several implications which are relevant to managers, academicians and future research. In order to maximise the profitability of firms, managers should put in the required effort to work within the range of the optimal working capital level since any deviation can have a negative impact on the profitability of the firm. The findings of this study extend research on the relevance of an effective and efficient working capital management. Lastly, due to the divergent findings of previous empirical studies, the relationship between working capital management and profitability might not be linear. Accordingly, it is recommended that subsequent studies should test for mediation/ moderation relationships.

\section{REFERENCES}

Afrifa, G., \& Tingbani, I. (2017). Working Capital Management, Cash Flow and SMEs' Performance. Munich Personal RePEc Archive, MPRA Paper No. 82894, 1-38. Online at https://mpra. ub.uni-muenchen.de/82894/.

Akinlo, O. O. (2013). Effect of Working Capital on Profitability of Selected Quoted Firms in Nigeria. Global Business Review, 13(3), 367-381.

Akoto, R. K., Awunyo-Vito, D., \& Angmor, P. L. (2013). Working capital management and profitability: Evidence from Ghanaian listed manufacturing firms. Journal of Economics and International Finance, 55, 373-379. DOI: 10.5897/JEIF2013.0539.

Aktas, N., Croci, E., \& Petmezas, D. (2018). Is working capital management value-enhancing? Evidence from firm performance and investments. Journal of Corporate Finance, 30, 98-113.

Alipour, M. (2011). Working Capital Management and Corporate Profitability: Evidence from Iran. World Applied Sciences Journal, 12(7), 1093-1099.

Ani, W. U., Okwo, M. I., \& Ugwunta, D. O. (2012). Effects of working Capital management in profitability: evidence from top five beer brewery firms in the world. Asian Economic and Financial Review, 2(8), 966-982.

Aregbeyen, O. (2013). The effects of working capital management on the profitability of Nigerian manufacturing firms. Journal of Business Economics and Management, 14(3), 520-534.

Arnold, G. (2008). Corporate financial management 4th edition. New York: Pearson education limited.

Arunkunar, O. N., \& Ramanan, T. R. (2013). Working Capital Management and profitability: A Sensitivity Analysis. International Journal of Research and Development: A Management review, 2, 52-58.

Deloof, M. (2003). Does working capital management affect profitability of Belgian firms? Journal of Business Finance and Accounting, 30(3-4), 573-587. http://doi.org/10.1111/1468-5957.00008. 
Dinku, T. (2013). Impact of Working Capital Management on Profitability of Micro and Small Enterprises in Ethiopia: The Case of Bahir Dar City Administration. International Journal of Accounting and Taxation, 1(1), 15-24. http://doi.org/10.15640/ijat.

Eljelly, M. A. (2004). Liquidity-Profitability Tradeoff: An Empirical Investigation in An Emerging Market. International Journal of Commerce \& Management, 14(2), 48-61.

Eramus, P. (2010). The Relationship Between Working Capital Management and Profitability for South African Listed Industrial Firms. The Business Review, 15(1), 183-188.

Evci, S., \& Şak, N. (2018). The Effect of Working Capital Management on Profitability in Emerging Countries: Evidence from Turkey. Financial Management from an Emerging Market Perspective, 205-218. http://dx.doi.org/10.5772/intechopen.70871.

Gachira, W., Chiwanzwa, W., Nkomo, D. J., \& Chikore, R. (2014). Working Capital Management and the Profitability of Non-Financial Firms Listed on the Zimbabwe Stock Exchange(ZSE). European Journal of Business and Economics, 9(2), 12-15.

Garcia-Teruel, P. J., \& Martınez-Solano, P. (2007). Effects of working capital management on SME profitability. International Journal of Managerial Finance, 3(2), 164-177. DOI 10.1108/17439130710738718.

Gill, A., Biger, N., \& Mathur, N. (2010). The Relationship Between Working Capital Management And Profitability: Evidence From The United States. Business and Economics Journal, Volume 2010, 10, 1-9.

Jana, D. (2018). Impact of Working Capital Management on Profitability of the Selected Listed FMCG Companies in India. International Research Journal of Business Studies, 11(1), 21-30. https://doi.org/10.21632/irjbs.

Kasiran, F. W., Mohamad, N. A., \& Chin, O. (2015). Working Capital Management Efficiency: A Study on the Small Medium Enterprise in Malaysia. 7th International Economics \& Business Management Conference, 5th \& 6th October 2015 (pp. 297 - 303). Procedia Economics and Finance.

Kasozi, J. (2017). The effect of working capital management on profitability: a case of listed manufacturing firms in South Africa. Investment Management and Financial Innovations, 14(2), 336-346.

Kodithuwakku, S. (2015). Impact of Working Capital Management on Profitability: A Study on Listed Manufacturing Companies in Colombo Stock Exchange. Proceedings of 12th International Conference on Business Management (pp. 1-13). Colombo: SSRN.

Korent, D., \& Orsag, S. (2018). The Impact of Working Capital Management on Profitability of Croatian Software Companies. Zagreb International Review of Economics \& Business, 21(1), 47-65. DOI: 10.2478/zireb-2018-0007.

Lazaridis, I., \& Tryfonidis, D. (2006). The relationship between working capital management and profitability of listed companies in the Athens Stock Exchange. Journal of Financial Management and Analysis, 19(1), 1-12. Electronic copy available at http://ssrn.com/abstract=931591.

Mathuva, M. D. (2010). The Influence of Working Capital Management Components on Corporate Profitability: A Survey on Kenyan Listed Firms. Research Journal of Business Management, 4(1), 1-11.

Napompech, K. (2012). Effects of Working Capital Management on the Profitability of Thai Listed Firms. International Journal of Trade, Economics and Finance, 3(3), 227-232.

Nazir, M. S., \& Afza, T. (2009). Impact of Aggressive Working Capital Management Policy on Firms' Profitability. The IUP Journal of Applied Finance, 15(8), 19-30.

Nikkinen, J., Graham, M., \& Enqvist, J. (2014). The impact of working capital management on firm profitability in different business cycles: Evidence from Finland. Research in International Business and Finance, 32, 36-49. 
Padachi, K. (2006). Trends in Working Capital Management and its Impact on Firms' Performance: An Analysis of Mauritian Small Manufacturing Firms. International Review of Business Research Papers, 2(2), 45-58.

Pais, M. A., \& Gama, M. P. (2015). Working capital management and SMEs profitability: Portuguese evidence. International Journal of Managerial Finance, 11(3), 341-358. https://doi. org/10.1108/IJMF-11-2014-0170.

Ponsian, N., Chrispina, K., Tago, G., \& Mkiibi, H. (2014). The effect of working capital management on profitability. International Journal of Economics, Finance and Management Sciences, 2(6), 347-355. doi: 10.11648/j.ijefm.20140206.17.

Prempeh, K. B. (2016). The Impact of Efficient Inventory Management on Profitability: Evidence from Selected Manufacturing Firms in Ghana. International Journal of Finance and Accounting, 5(1), 22-26. DOI: 10.5923/j.ijfa.20160501.03.

Raheman, A., \& Nasr, M. (2007). Working Capital Management And Profitability - Case Of Pakistani Firms. International Review of Business Research Papers, 3(1), 279-300.

Ray, S. (2012). Evaluating the Impact of Working Capital Management Components on Corporate Profitability: Evidence from Indian Manufacturing Firms. International Journal of Economic Practices and Theories, 2(3), 127-136.

Sharma, A. K., \& Kumar, S. (2011). Effect of Working Capital Management on Firm Profitability: Empirical Evidence from India. Global Business Review, 12(1), 159-173.

Ukaebe, B. (2014). The significance of working capital management in determining firm profitability: Evidence from developing economies in Africa. Research in International Business and Finance, 31, 1-6. http://dx.doi.org/10.1016/j.ribaf.2013.11.005.

Uyar, A. (2009). The Relationship of Cash Conversion Cycle with Firm Size and Profitability: An Empirical Investigation in Turkey. International Research Journal of Finance and Economics (24), 186-193.

Vahid, T. K., Elham, G., Mohsen, A. k., \& Mohammadreza, E. (2012). Working capital management and corporate performance: evidence from Iranian companies. Procedia - Social and Behavioral Sciences, 62(2012), 1313-1318. 


\section{APPENDIX}

Table 1: Descriptive Statistics

\begin{tabular}{|c|c|c|c|c|}
\hline \multicolumn{5}{|c|}{ ROA (Return on Assets) } \\
\hline & Percentiles & Smallest & & \\
\hline $1 \%$ & -4.6402 & -4.6402 & & \\
\hline $5 \%$ & -.1582 & -.418 & & \\
\hline $10 \%$ & -.1096 & -.3466 & Observation & 77 \\
\hline $25 \%$ & -.0118 & -.1582 & Sum of Wgt. & 77 \\
\hline $50 \%$ & .068 & Largest & Mean & .0011455 \\
\hline & & & Std. Dev. & .5519027 \\
\hline $75 \%$ & .1325 & .2965 & & \\
\hline $90 \%$ & .2253 & .2975 & Variance & .3045966 \\
\hline $95 \%$ & .2965 & .303 & Skewness & -7.866646 \\
\hline $99 \%$ & .3042 & .3042 & Kurtosis & 66.69508 \\
\hline \multicolumn{5}{|c|}{ CCC (Cash Conversion Cycle) } \\
\hline & Percentiles & Smallest & & \\
\hline $1 \%$ & -1510.595 & -1510.595 & & \\
\hline $5 \%$ & -169.849 & -376.0636 & & \\
\hline $10 \%$ & -116.2765 & -222.579 & Observation & 77 \\
\hline $25 \%$ & -22.9956 & -169.849 & Sum of Wgt. & 77 \\
\hline \multirow[t]{2}{*}{$50 \%$} & 50.9293 & Largest & Mean & 34.2048 \\
\hline & & & Std. Dev. & 219.6184 \\
\hline $75 \%$ & 126.1304 & 285.3063 & & \\
\hline $90 \%$ & 233.9506 & 287.8087 & Variance & 48232.24 \\
\hline $95 \%$ & 285.3063 & 298.0379 & Skewness & -4.568945 \\
\hline $99 \%$ & 332.701 & 332.701 & Kurtosis & 33.06137 \\
\hline \multicolumn{5}{|c|}{ CR (Current Ratio) } \\
\hline & Percentiles & Smallest & & \\
\hline $1 \%$ & .0358 & .0358 & & \\
\hline $5 \%$ & .4313 & .1969 & & \\
\hline $10 \%$ & .5364 & .3253 & Observation & 77 \\
\hline $25 \%$ & .8394 & .4313 & Sum of Wgt. & 77 \\
\hline \multirow[t]{2}{*}{$50 \%$} & 1.4155 & Largest & Mean & 2.132342 \\
\hline & & & Std. Dev. & 2.126788 \\
\hline $75 \%$ & 2.0223 & 6.8096 & & \\
\hline $90 \%$ & 6.5881 & 6.9424 & Variance & 4.523229 \\
\hline $95 \%$ & 6.8096 & 7.6849 & Skewness & 1.748935 \\
\hline $99 \%$ & 9.8065 & 9.8065 & Kurtosis & 5.151857 \\
\hline
\end{tabular}




\begin{tabular}{|c|c|c|c|c|}
\hline \multicolumn{5}{|c|}{ Lev (Leverage) } \\
\hline & Percentiles & Smallest & & \\
\hline $1 \%$ & -1.3285 & -1.3285 & & \\
\hline $5 \%$ & .0673 & .0519 & & \\
\hline $10 \%$ & .0958 & .0672 & Observation & 77 \\
\hline $25 \%$ & .5028 & .0673 & Sum of Wgt & 77 \\
\hline \multirow[t]{2}{*}{$50 \%$} & .8569 & Largest & Mean & 19.0804 \\
\hline & & & Std. Dev. & 138.0642 \\
\hline $75 \%$ & 2.367 & 9.1509 & & \\
\hline $90 \%$ & 6.4483 & 10.7535 & Variance & 19061.71 \\
\hline $95 \%$ & 9.1509 & 130.6352 & Skewness & 8.460465 \\
\hline $99 \%$ & 1207.91 & 1207.91 & Kurtosis & 73.29153 \\
\hline \multicolumn{5}{|c|}{ SIZE (Size of Firm) } \\
\hline & Percentiles & Smallest & & \\
\hline $1 \%$ & 5.6582 & 5.6582 & & \\
\hline $5 \%$ & 6.3115 & 6.2709 & & \\
\hline $10 \%$ & 6.4784 & 6.3089 & Observation & 77 \\
\hline $25 \%$ & 6.682 & 6.3115 & Sum of Wgt & 77 \\
\hline \multirow[t]{2}{*}{$50 \%$} & 7.6135 & Largest & Mean & 7.430229 \\
\hline & & & Std. Dev. & .6875276 \\
\hline $75 \%$ & 7.9249 & 8.4505 & & \\
\hline $90 \%$ & 8.3031 & 8.4659 & Variance & .4726942 \\
\hline $95 \%$ & 8.4505 & 8.5065 & Skewness & -.3804045 \\
\hline $99 \%$ & 8.5097 & 8.5097 & Kurtosis & 2.146934 \\
\hline
\end{tabular}

Source: Field data, 2018 